た。その結果，被害茥率は平均 $10.0 \%$, 変色茥桃は平均 $1.4 \%$ で，変色茥の被㕩苳に占める割合は $1 / 4$ 〜1/10のもの が多かった。

収穫物における食入部位は茎先端部のものが50〜 $60 \%$ を占めるが，これらは外見上ほとんどその被害がめだた ず，荃元附近のものは20 30\%で，変色菱となるものが 多かった。

今後はさらに本害忠の収量に対する影響等について明 らかにしたい。

\begin{abstract}
参考 文 献
1) 高知県農事試験場 (1970)：いぐさに関する試験成精 書, 13-18, (乙う写) 2) 熊本農試八代支場 (1965): 全国い業研究会資料，109，(と5写）3）野津六兵簿 (1963)：島根農試研觉報告, 6, 1-18 4) 鬼木正臣 (1970)：農楽，17(3)，26-29 5) 高山炤夫・吉岡幸治 郎・上田進 - 行本義行 (1965)：愛湲農試研究報告, 5, 49-53 6) 山本辰夫(1968): 農業香川, 5(20)，88-89 7) 楖原秀康・常楽武男 - 浅田俊雄 - 西良太郎 - 石黒久 信 (1966)：畜山農試研究報告，1，189-194
\end{abstract}

\title{
ニカメイチュウに対するダィアジノン微粒戍の施用条件と効果
}

\author{
ピニット ニルパニット（タイ国稻作保荠研究センター） \\ 永田徹・前田 洋一・守谷 茂雄 (九州農業試験場)
}

\section{Effect of diazinon fine granule on rice stem borer, Chilo suppressalis Walker.}

Pinit NilPanit (Rice Protection Research Center, Thailand)

Toru Nagata, Yoichi MaEda and Shigeo MoriYa (Kyushu Agricultural Experiment Station)

In a field trial of small scale, the effect of fine granule of diazinon, $5 \%$ a. i., 100-300 micron in diameter, was investigated against rice stem borer with special references to the application method and the presence of irrigation water in the paddy field. The fine granule was applied at a rate of $40 \mathrm{~kg}$ (a. i. $2 \mathrm{~kg}$ ) per ha (1) from the top of plant with irrigation water, (2) from the top at dried condition (3) on the soil surface at dried condition. Water supply in (2) and (3) was not made 6 days before and after the application of granule. The moisture content of soil just before the application was about $24 \%$.

Rice stem borer was innoculated by fixing egg-masses on paper to leaf sheath of rice plant. Twenty five egg-masses, composed of ca. 50 eggs each, were set for one plot. The infestation was made at two seperate times, 7 days before and just before the application. In the former, eggs at black head stage were set, so that the hatched larvae were to have bored into rice stem 4 to 5 days before the application. In the latter, eggs at middle stage were used, so that the boring of larvae was to occur after the application.

When the fine granule was applied from the top of plant already infested, it showed satisfactory control effect both at irrigated and dried condition. Larvae were completely killed and number of injured stem reduced significantly. On the contrary, the granule applied on the soil surface of dried field was less effective.

When the granule was applied before hatching of the borer, no reduction of injured stems was found, suggesting that the rice plant could not be protected from infestation by hatched larvae. However, at the plots where the granule was applied from the top of plant, mortality of larvae found in the stems was more than $90 \%$ and the hatchability of innoculated eggs was also reduced apparently.

These results suggest that the insecticidal effect of diazinon fine granule is mainly attributed to the action of fine granule particles attached to the plant but less to the active ingredient penetrated or absorbed through irrigation water. The eggs and larvae could be partly affected through other actions, such as, vaporized ingredient.

水中施薬に用いられている粒剂形驡の殺虫剂は，主と して有効成分が水中て溶解，搪散し，植物体内一浸透移 行してから殺虫力を発揮するものとされている。しか し，蒸気圧の高い薬剤の場合には蒸散ガスによる殺虫力 も大きく，湖山ら(1968) はほ場においてもウンカ, ヨ コバイ類に対してダイアジノンなどの薬剤が主としてガ
ス態で作用していると指摘している。近来開発されてい る新㓲型の1つである微粒剤は，ドリフト防止を主目的 としており，從来の粒戍とは異なった作用を示すことが 考えられる。筆者らはダイアジン微粒片を用い，施用 時の条件，方法と二カメイチュウに対する効果について 調べ，その作用性を検討した。 


\section{試験 方 法}

水田に設けた $1.7 \times 1.7 \mathrm{~m}$ わくに 6 月 5 日, 稲苗（品 種：レイホウ) $8 \times 8$ 列, 合計 64 株ずつ植えつけ, 慣 行により栽培した。6 月以降自然飛来するニカメイチュ ウによる産郋は随時採卵するかあるいは被害葉を早目に 取り除いて食入を防いだ。

このほ場に時期を変えてニカメイチュウの卵塊接種を 行なってから薬剤を施用し, 食入後施薬区と食入前拖薬 区を設けた。食入後施楽区では施薬 7 日前にふ化直前の 眀塊を各区中心部の水稻葉䩗部（高さ $15 \mathrm{~cm}$ ）に1区当た り 25 畉塊（約 50 即/ 1 畉塊）を接種し，2日後に大部分 の卵がふ化したことを確認して残卵を回収した。また食 入前施薬区では，ふ化 3〜4 日前の㽗塊を施薬直前に同 様の方法で接種し，6日後に残卵を回収した。

薬剮はダイアジノン微粒剤（有效成分量 $5 \%$ ，粒佳 $100 \sim 300 \mu ）$ を用い， 7 月21日， $4 \mathrm{~kg} / 10 \mathrm{a}$ の割合で， 上部少ら水稲萃葉部にふりかけるように（茎葉散布施用 区）または株間地面のみに均一に散布されるように（地 面施用区）手まきした。この両処理に湛水区，無湛水区 を組合わせて試験を行なった。各処理 1 連制。なお，無 湛水区では施薬の前後 6 日間かん水を行なわなかった が, 施薬 7 日後より稻の萎淍を防ぐため最小限のかん水 を再開した。施薬時における無湛水区の土境の外観は水 分による光沢が認められない程度の黒乾状態で，施薬直
前の土壤含水量注平均 $24.1 \%$ であった。

食入後施薬区については施薬 6 日後に 1 区当たり12株 を刈り取って分解調查により食入状況を調べ，全株につ いて被害茎数を求めた。食入前施薬区では接種13日後に 同样の調查を行なったほか，接種 6 日後に回収した卵塊 のふ化状況を調查した。

\section{結果および考察}

食入後に施薬した場合，Table $1 ， 2$ に示したよう に，水稻地上部に薬㓮が付着するよう散布した茥葉散布 施用区では，湛水の有無にかかわらず在虫数や被害茎数 が減少しており，高い食入虫殺虫効果が認められた。こ れに対し，無湛水地面施用区では在虫数は無処理区より 明らかに減少していることが認められるが，被害茎数は かなり多く，効果は少った。

このように茎葉部散布施用が湛水の有無と関係なく高 い殺虫効果を示したことは，微粒剤が茎葉部に付着する ことによって粉剤と類似の，恐らく浸透移行による殺虫 効果を示したものであり，水地面に落下した微粒剤によ るいわゆる水面施用的効果はほとんど筒与していないよ うにみえる。しかし，地面施用の場合，土壤水分量加ら 考元て水に上る有效成分の移動はないとみられるのに在 禹数が減少していることは，あとで述べるように，水を 媒体とした植物体への吸収以外の経路によってダイアジ ノンが何らかの作用を示したものと考兊られる。

Table 1. Number of injured stems and larvae obtained from the hills sampled in the fields where granules were applied $4-5$ days after infestation with rice stem borer.

\begin{tabular}{l|c|c|c|c}
\hline \multicolumn{1}{c|}{ Treatment } & $\begin{array}{c}\text { No. of hills } \\
\text { sampled }\end{array}$ & $\begin{array}{l}\text { No. of stems } \\
\text { sampled }\end{array}$ & $\begin{array}{l}\text { No. of stems } \\
\text { injured }\end{array}$ & $\begin{array}{c}\text { No. of larvae found } \\
\text { Total (Dead) }\end{array}$ \\
\hline $\begin{array}{l}\text { Application from the top of } \\
\text { plant in dried field }\end{array}$ & 12 & 272 & 7 & $0(0)$ \\
$\begin{array}{l}\text { Application on the soil } \\
\text { surface in dried field }\end{array}$ & 12 & 270 & 38 & $25(2)$ \\
$\begin{array}{l}\text { Application from the top of } \\
\text { plant in irrigated field }\end{array}$ & 12 & 276 & 5 & $1(0)$ \\
Untreated & 12 & 276 & 35 & $351(19)$ \\
\hline
\end{tabular}

Table 2. Number of injured hills and stems obtained by examining total hills of each plot where granules were applied 4-5 days after infestation.

\begin{tabular}{l|c|c|c|c}
\hline \multicolumn{1}{c|}{ Treatment } & $\begin{array}{l}\text { No. of hills } \\
\text { sampled }\end{array}$ & $\begin{array}{l}\text { No. of hills } \\
\text { injured }\end{array}$ & $\begin{array}{l}\text { No. of stems } \\
\text { injured }\end{array}$ & $\%$ injured stem \\
\hline $\begin{array}{l}\text { Application from the top of } \\
\text { plant in dried field }\end{array}$ & 64 & 15 & 22 & 1.5 \\
$\begin{array}{l}\text { Application on the soil } \\
\text { surface in dried field }\end{array}$ & 64 & 64 & 399 & 27.7 \\
$\begin{array}{l}\text { Application from the top of } \\
\text { plant in irrigated field }\end{array}$ & 64 & 12 & 1.5 & 1.0 \\
Untreated & 64 & 63 & 201 & 13.6 \\
\hline
\end{tabular}


Tuble 3. Number of injured stems and larvae obtained from the hills sampled in the
fields where granules were applied before infestation with rice stem borer.

\begin{tabular}{l|c|c|c|c}
\hline \multicolumn{1}{c|}{ Treatment } & $\begin{array}{l}\text { No. of hills } \\
\text { sampled }\end{array}$ & $\begin{array}{l}\text { No. of stems } \\
\text { sampled }\end{array}$ & $\begin{array}{l}\text { No. of stems } \\
\text { injured }\end{array}$ & $\begin{array}{c}\text { No. of larvae found } \\
\text { Total (Dead) }\end{array}$ \\
\hline $\begin{array}{l}\text { Application from the top of } \\
\text { plant in dried field }\end{array}$ & 8 & 164 & 47 & $138(125)$ \\
$\begin{array}{l}\text { Application on the soil } \\
\text { surface in dried field }\end{array}$ & 8 & 163 & 26 & $124(27)$ \\
$\begin{array}{l}\text { Application from the top of } \\
\text { plant in irrigated field }\end{array}$ & 8 & 152 & 39 & $131(119)$ \\
Untreated & 8 & 172 & 56 & $228(29)$ \\
\hline
\end{tabular}

Table 4. Number of injured hills and stems obtained by examining total hills of each plot where granules were applied before infestation.

\begin{tabular}{l|c|c|c|c}
\hline \multicolumn{1}{c|}{ Treatment } & $\begin{array}{l}\text { No. of hills } \\
\text { sampled }\end{array}$ & $\begin{array}{l}\text { No. of hills } \\
\text { injured }\end{array}$ & $\begin{array}{l}\text { No. of stems } \\
\text { injured }\end{array}$ & \% injured stem \\
\hline $\begin{array}{l}\text { Application from the top of } \\
\text { plant in dried field }\end{array}$ & 64 & 38 & 108 & 8.2 \\
$\begin{array}{l}\text { Application on the soil } \\
\text { surface in dried field }\end{array}$ & 64 & 59 & 163 & 12.5 \\
$\begin{array}{l}\text { Application from the top of } \\
\text { plant in irrigated field }\end{array}$ & 64 & 23 & 60 & 4.9 \\
Untreated & 64 & 24 & 109 & 7.9 \\
\hline
\end{tabular}

畉のふ化前に施薬した場合，いずれの処理区でもかな りの在虫数が琶められ，また被害茎数は湛水区がやや低 かったほかは無処理区との恙が認められず，食入防止效 果はきわめて小さいものと考えられる。しかし，この場 合でも辰葉部散布施用区での死虫率は90\%以上を示した が，地面施用区では低かった。これは食入後施楽した場 合と同様，䔄葉部に付着した微粒剂の効果が纤虫の食入 後に現われたものと思われる。また，施薬区では接種畉 のふ化率の低下が認められ，特に茥葉散布施用区ではふ 化率の低い卵塊が過半数を占めた。期の接種条件などか らみても薬剤の浸透移行による影響とは考えられず，ガ ス化したダイアジンまたは付着した薬剤粒子による作 用と思われる。

このようにダイアジノン微粒剤は稲茥葉部への散布施 用を行なえば，田面水を欠いた場合でも食入した二カメ イチュウを殺虫できる。その作用は水地面に落下した薬 剂によるよりも，茥葉部に付着した微粒剂による散布剤 的効果が主体であり，この効果は通常の粉剤使用時にお けるよりもはるかに多い投下有効成分量によって増強さ れていると考えられる。

しかし，地面施用の場合にも若千の効果が見られたこ とについては，浸透移行あるいは楽用の接触作用以外に 何らかの作用，例えば薬剂から揮政したガスの作用など が関与していることも推測される。別に行なった類似条 件の試験において，化学分析の結果，無たん水状態で地
面に施薬 6 日後に葉䩪部 $0.03 \mathrm{ppm}$, 葉身部 $0.09 \mathrm{ppm}$ のダイアジンが検出されている。この検出量は同時に 行なった水中施薬の場合のほぼ $1 / 2 に$ 相当する。このこと は微粒剤から蒸散したガスが植物体に吸着されあるいは

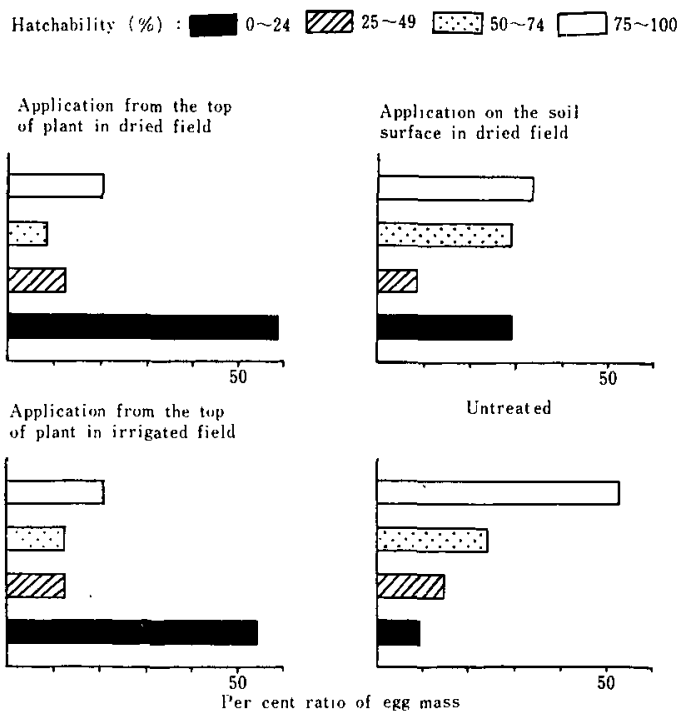

Fig. 1. Reduction in the hatchability of eggs by application of granules just after innoculation. Each pile indicates the ratio of egg mass which showed appointed grade of hatchability. 
さらに浸透移行したものと推定せざるを得ない。このよ うな形のダイアジノンがニカメイチュウ防除に占める役 割は大きくないと考えられるが，さらに㛟討が必要であ ろう。
参 考 文 献

1) 湖山利篤・鶴町昌市 (1968)：応動昆， 12，156-163

2) 平野千里・湯島湕 (1969): 応動辰, 13, 174-184 3) 升田武夫・福田秀夫(1970)：防虫科学，35，134-140

\section{ニカメイチュウ，ウンカ・ヨコバイ類に対するパイプダスター散布による \\ 各種粉粒剂の同時防除効果について}

（その1）重質粉剈を中心に

有薗敏 雄(佐賀県植物病害虫防除所)

宮原和夫・阿部恭洋 (佐賀県農業試験場)

はじめに

佐賀県では，水槄病害虫防除のための薬骫散布機とし て,パイプダスターが使われはじわてからすでに数年経 過している。しかしパイプダスターによる粉剈の散布は 散布時の気象や稻の生去状況などに影響されて，防除効 果があがらないことがしばしばあった。また散布地域外 への薬剤の飛散（ドリフト）が著しく，公害防止の面か らも好ましくない。本年度は，このような粉剤の欠点を 改良してつくられた重質粉剤, 粉粒剤, 微粒剤などの新 しい農薬をパイプダスターで散布し，それらの防除効果 について比較検討したので，ここに調查結果の概要を報 告する。

\section{試 験 方 法}

佐賀郡川副町南里, 県農業研修学園ほ場において第 1 表に示すような蒋冎を，7月17日（1部21日）に，10 a 当り $3 \mathrm{~kg}$ （粉粒珴は $4 \mathrm{~kg}$ ）前後, また 8 月20日と31日に $10 \mathrm{a}$ 当り $4 \mathrm{~kg}$ (粉䉺片は $5.3 \mathrm{~kg}$ ) 前後を背負式動力散粉散 粒ミスト兼用機（共立 DM-9，20m パイプ）で散布し
た。散布時には防除効果に影響の大きいとみられる気象 や稻の生育状濯について調查した。

つぎに薬剤の防除効果をみるため，二カメイチュウ第 1 世代虫について 7 月 28 日および 8 月 5 日各区 180 株当 りの被害茎数を, ツマグロヨコバイについては 7 月16日, 20日，22日，28日各区40株当りの虫数を払い落とし法によ って調查した。また二カメイチュウ第 2 世代虫について 10月21日の刚取時に各区 200 株当たりの被害茥数を，ま たトビイロウンカとツマグロヨコバイについては，8月 18日から9月22日まで計 8 回, 备区 40 株当りの虫数を払 い落とし法によって調査した。

また薬骺の稲体付着状況，水面落下状沅，ドリフトな どについても調査した。

\section{結果および考察}

1. 薬剤散布時の気解状況

ニカメイチュウ第 1 世代虫を対象に薬剈を散布した 7 月17日と21日は, 早朝から 2 7 m/sec の風がふいてい た。

またニカメイチュウ第 2 世代虫を対象に薬剤を散布

第 1 表 供試薬 片 $の$ 種類

\begin{tabular}{|c|c|c|c|c|c|c|c|c|c|}
\hline \multirow{2}{*}{ 商 品 名 } & \multirow{2}{*}{ 主 } & \multirow{2}{*}{ 成 } & \multirow{2}{*}{ 分 } & \multirow{2}{*}{$\begin{array}{l}1 \text { 笠の } \\
\text { 重 }\end{array}$} & \multicolumn{4}{|c|}{ 粒子の混合割合 } & \multirow{2}{*}{ 備 } \\
\hline & & & & & 粒剂 & 微粒郕 & 粗粉剂 & 粉剂 & \\
\hline 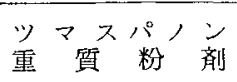 & $\begin{array}{l}\text { クㅁㄱㄱ } \\
\text { MTMC }\end{array}$ & ミシン & $\begin{array}{l}2.0 \% \\
2.0\end{array}$ & 3 & $0^{\%}$ & $45 \%$ & 55 & $\%$ & \\
\hline 唯マスパノノ粒 剂 & 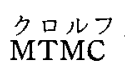 & シジン & $\begin{array}{l}2.0 \\
2.0\end{array}$ & 3 & 0 & 100 & 0 & 0 & \\
\hline 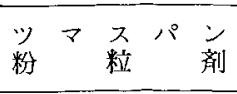 & 名믁글 & & $\begin{array}{l}3.0 \\
2.0\end{array}$ & 4 & 50 & 0 & 0 & 50 & 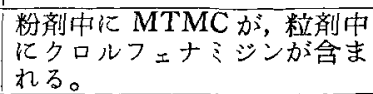 \\
\hline 分ダンサイド & $\begin{array}{l}\text { カル夕ッ } \\
\text { MTMC }\end{array}$ & & $\begin{array}{l}2.6 \\
1.5\end{array}$ & 4 & 50 & 0 & 0 & 50 & $\begin{array}{l}\text { 粉剤中に MTMC が，粒剂 } \\
\text { 中にカルタップが含まれる。 }\end{array}$ \\
\hline ゴマパダンサイド & $\begin{array}{l}\text { カルタッ } \\
\text { MTMC }\end{array}$ & & $\begin{array}{l}2.2 \\
2.0\end{array}$ & 3 & 33.3 & 0 & 0 & 66.6 & 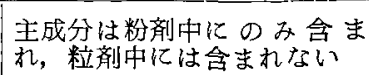 \\
\hline
\end{tabular}

